\title{
APLIKASI JOB FAIR BERBASIS WEB PADA DINAS SOSIAL TENAGA KERJA DAN TRANSMIGRASI KALIMANTAN SELATAN
}

\author{
Sefto Pratama ${ }^{1)}$ \\ ${ }^{1}$ Fakultas Teknologi Informasi, Universitas Islam Kalimantan Muhammad Arsyad Al Banjari (Sefto Pratama) \\ Email : seftopratama.bjm@gmail.com
}

\begin{abstract}
ABSTRAK
Proses penginputan data di Dinas Sosial Tenaga Kerja dan Transmigrasi Kalimantan Selatan masih menggunakan sistem semi komputerisasi. Kebanyakkan dari penginputan data-datanya masih bersifat umum walaupun sudah menggunakan computer dan banyak juga yang masih dalam bentuk berkas fisik, namun belum memanfaatkan adanya komputer tersebut secara maksimal. Seperti data Perusahaan, data Pelamar dan data posisi lowongan kerja. Data-data tersebut belum terorganisir dan diolah dengan baik, sehingga akan menjadi masalah jika dikelola secara manual, karena selain tingkat kesalahan yang tinggi, juga membutuhkan waktu yang lama dalam penyusunan laporan. Untuk mengatasi permasalahan tersebut, maka diperlukan sebuah Aplikasi Job Fair pada Dinas Sosial Tenaga Kerja dan Transmigrasi Kalimantan Selatan. Aplikasi ini dibangun dengan menggunakan metode waterfall yang umum digunakan dalam pembuatan aplikasi. Ada beberapa tahap dalam pengembangan aplikasi ini, yaitu tahap analisis, desain, koding, pengujian dan implementasi. Aplikasi ini menggunakan desain sistem Data Flow Diagram. Sedangkan pada tahap koding, aplikasi ini dibangun menggunakan bahasa pemrograman PHP dengan database MySQL. Dengan adanya aplikasi ini diharapkan pengguna dapat lebih mudah dalam menginput data pelamar, data perusahaan dan data posisi lowongan kerja, sehingga lebih efektif dan efisien.
\end{abstract}

Keywords : Aplikasi, Job Fair, Berbasis Web

\section{PENDAhuluan}

Perbandingan jumlah yang sangat besar tejadi dimasyarakat sekarang ini yaitu pertumbuhan masyarakat pencari kerja dengan lapangan pekerjaan yang tidak seimbang membuat permasalahan yang mengakibatkan kesenjangan ekonomi dan sosial dimasyarakat, membuat perluasan lapangan kerja menjadi prioritas utama dalam pembangunan ketenagakerjaan. Sejalan dengan pertumbuhan angkatan kerja yang tidak seimbang dengan kesempatan kerja yang tersedia, membawa dampak pengangguran yang memerlukan penanganan serius oleh berbagai pihak, salah satu alternatif atau upayanya adalah penempatan atau penyaluran tenaga kerja.

Salah satu media yang dapat menjembatani antara penyedia kerja (perusahaan) dengan pencari kerja dalam penyampaian informasi lapangan pekerjaan yaitu melalui Job Fair. Dengan adanya Job Fair, diharapkan dapat memberikan informasi lapangan pekerjaan terhadap pencari kerja yang membutuhkan pekerjaan, pastinya sesuai dengan skill atau kemampuan yang dimilikinya (Dwi $\mathrm{dkk}, 2006$ ).

Sistem Informasi Job Fair di Dinas Sosial Tenaga Kerja masih semi komputerisasi. Walaupun sudah menggunakan komputer, namun pemanfaatannya belum maksimal, penginputan data-datanya masih bersifat umum. Seperti data perusahaan, data pelamar dan data posisi lowongan kerja. Data-data tersebut belum terorganisir dan diolah dengan baik sehingga akan menjadi masalah jika dikelola secara manual karena selain tingkat kesalahan yang tinggi, juga membutuhkan waktu yang lama dalam penyusunan laporan.

Dari penjelasan tersebut maka dibutuhkan suatu sistem dalam menyajikan informasi pengolahan data dalam Job Fair. Sehingga penulis mempunyai ide/gagasan untuk membuat "Aplikasi Job Fair Berbasis WEB 
Pada Dinas Sosial Tenaga Kerja Dan Transmigrasi Kalimantan Selatan".

\section{METODE PENELITIAN}

Pada penelitian ini penulis menggunakan beberapa metode pengumpulan data sebagai berikut :

a. Metode Observasi

Observasi atau pengamatan merupakan salah satu teknik pengumpulan data atau fakta yang cukup efektif untuk mempelajari suatu sistem. Observasi adalah pengamatan langsung para pembuat keputusan berikut lingkungan fisiknya atau pengamatan langsung suatu kegiatan yang sedang berjalan. Pada tahap ini penulis melakukan pengamatan terhadap kegiatan, proses, dan alur masuk dan bagaimana sebuah sistem pencatatan berjalan.

b. Metode Wawancara

Wawancara merupakan salah satu teknik pengumpulan data yang penting dan banyak dilakukan dalam pengembangan sistem informasi. Wawancara memungkinkan analis sistem sebagai pewawancara untuk mengumpulkan data secara tatap muka langsung dengan orang yang diwawancarai. Adapun orang-orang yang diwawancarai adalah Petugas Gudang dan staff admin pada Dinas Sosial Tenaga Kerja dan Transmigrasi Kalimantan Selatan tersebut

Analisis sistem adalah suatu proses mengumpulkan dan menginterpretasikan kenyataan-kenyataaan yang ada, mendiagnosa persoalan dan menggunakan keduanya untuk memperbaiki sistem. Pada tahap ini penulis lakukan adalah :

a. Mengidentifikasi masalah untuk mendapat pengertian sebenarnya dari masalah yang dihadapi yaitu dengan mengidentifikasikan penyebab masalah dan bagaimana langkah untuk menyelesaikannya.

b. Memahami sistem kerja yang ada dengan mengumpulkan data hasil penelitian dan memahami sistem yang ada.

c. Menganalisa kelemahan sistem dan kebutuhan informasi

Tahapan Penelitian
Tahapan penelitian ini antara lain :

1. Pengajuan proposal penelitian

2. Penentuan objek penelitian

3. Kajian teori untuk menentukan kriteria

4. Pengumpulan data primer dan sekunder

5. Pengolahan data

6. Pembuatan sistem

7. Pengujian sistem

8. Pembuatan laporan

Seminar hasil penelitian Uraikan secara rinci metode yang akan digunakan meliputi tahapan-tahapan penelitian, lokasi penelitian, peubah yang diamati/diukur, model yang digunakan, rancangan penelitian, serta teknik pengumpulan dan

analisis data. Untuk penelitian yang menggunakan metode kualitatif perlu dijelaskan pendekatan yang digunakan, proses pengumpulan dan analisis informasi, serta penafsiran dan penarikan kesimpulan penelitian.

\section{HASIL DAN PEMBAHASAN}

Hasil Pengumpulan Data

a. Metode Observasi

Observasi pertama dilaksanakan pada bulan september 2017, dengan tujuan untuk melakukan pengamatan langsung terhadap sistem yang berjalan pada objek

b. Metode Wawancara

Wawancara dilakukan kepada Bidang Penempatan dan Perluasan Kerja, Seksi Informasi Pasar Kerja, Seksi Pelatihan dan Produktifitas Kerja, Seksi Penempatan Tenaga Kerja, Wawancara lebih banyak dilakukan dengan komunikasi via Telpon dan Chat, karena keterbatasan waktu untuk bisa bertemu secara langsung

\section{Hasil Temuan}

Hasil temuan yang didapatkan setelah melakukan analisa dan pengumpulan data adalah sebagai berikut :

a. Banyak berkas yang hanya disimpan dilemari sehingga data penting tentang informasi perusahaan tidak di perbaharui. 
b. Pergantian KA Bidang Penempatan dan Perluasan Kerja, dan seksi-seksinya mempunyai pengaruh dalam menggunakan sistem terdahulu.

c. Tidak adanya sistem yang menyimpan data tentang perusahaan ataupun pencari kerja secara terstruktur dan berkala.

Implementasi Sistem

a. Form Login d. Hal itu terjadi karena sistem yang ada hanya dibuat secara desktop dan berkas fisik sehingga berkas yang telah ada hanya disimpan dan banyak yang rusak.

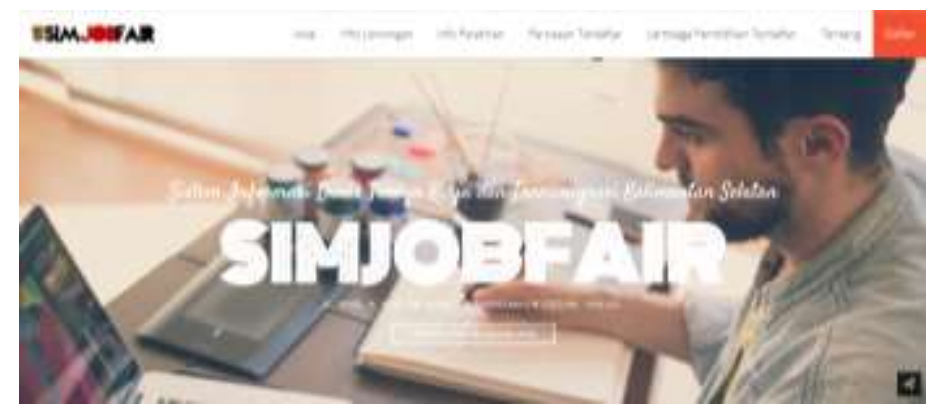

Gambar 1. Form Login

b. Form Daftar

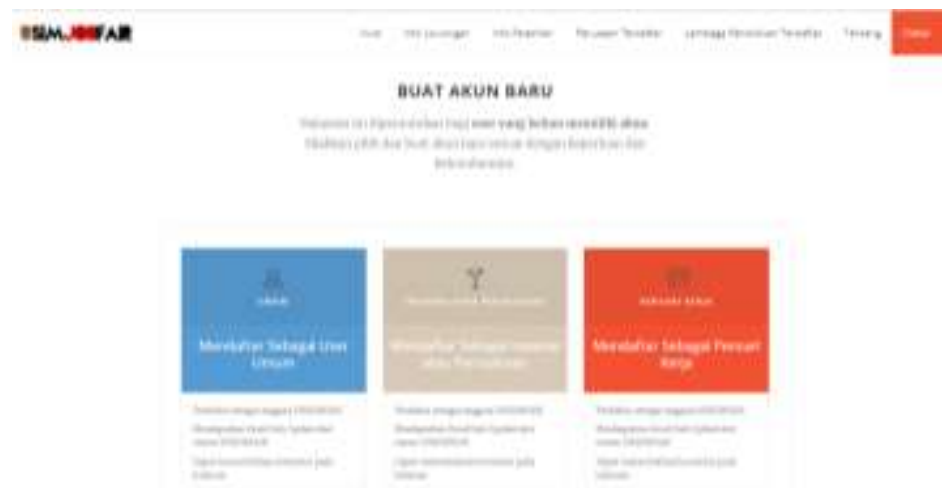

Gambar 2. Form Daftar

c. Form Daftar Sebagai Umum
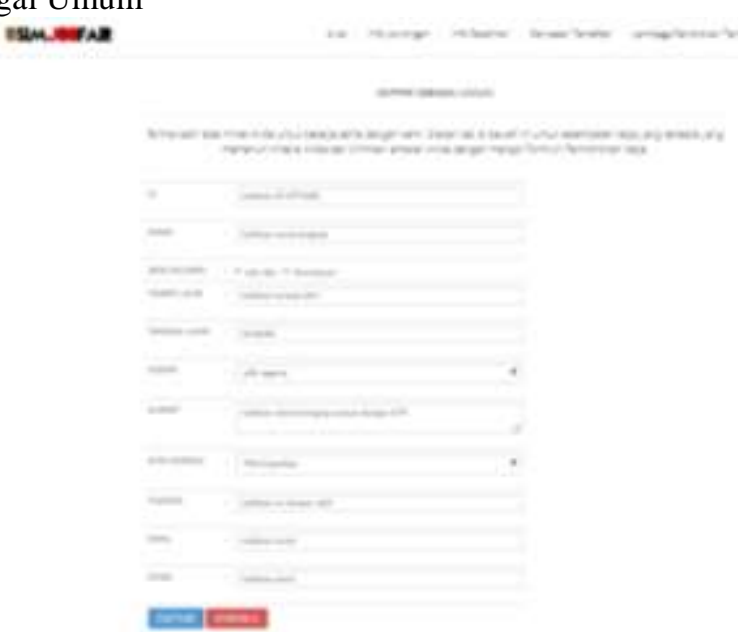

Gambar 3. Form Daftar Sebagai Umum 
d. Form Daftar Sebagai Instansi/Perusahaan

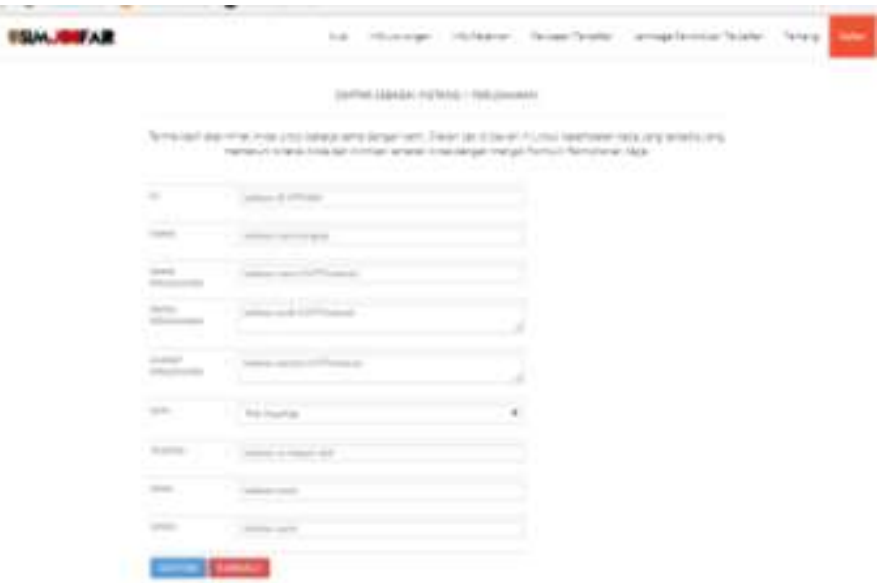

Gambar 4. Form Daftar Sebagai Instansi/Perusahaan

e. Form Daftar Sebagai Pelamar/Pencari Kerja

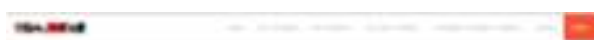

Gambar 5. Form Daftar Sebagai Pelamar/Pencari Kerja

f. Form Input Lowongan Pekerjaan

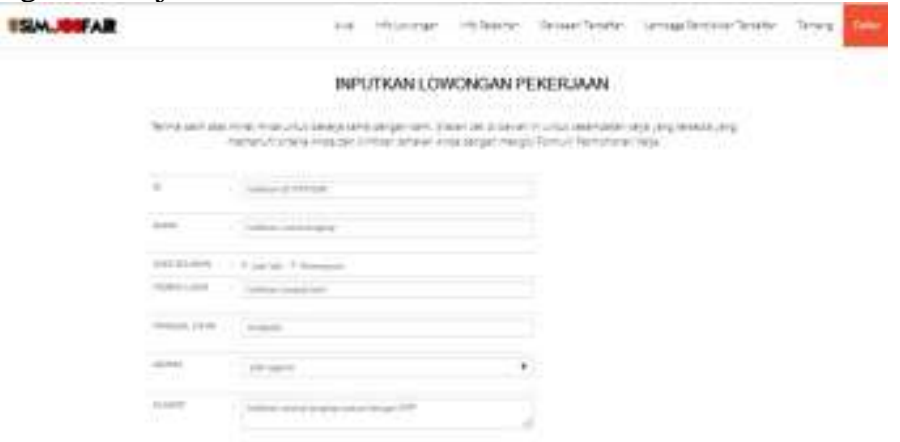

Gambar 6. Form Input Lowongan Pekerjaan

g. Form Data Pendaftar Umum

Jurnal Ilmiah "Technologia" 


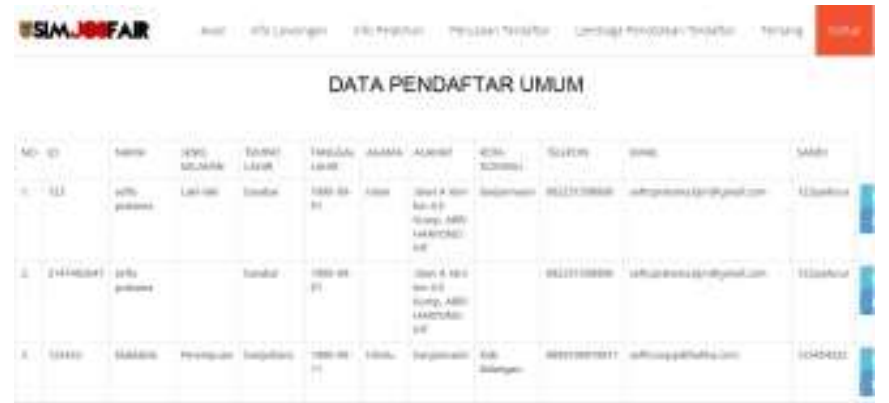

Gambar 7. Form Data Pendaftar Umum

h. Form Perusahaan/Instansi Terdaftar

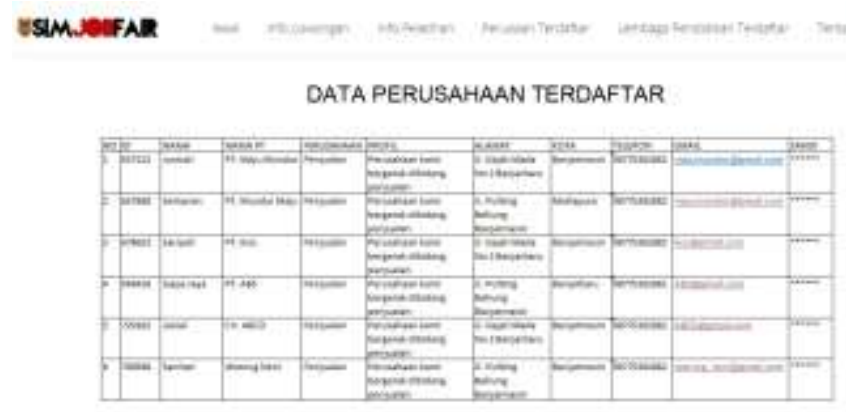

Gambar 8. Form Perusahaan/Instansi Terdaftar

i. Form Data Pencari Kerja Terdaftar

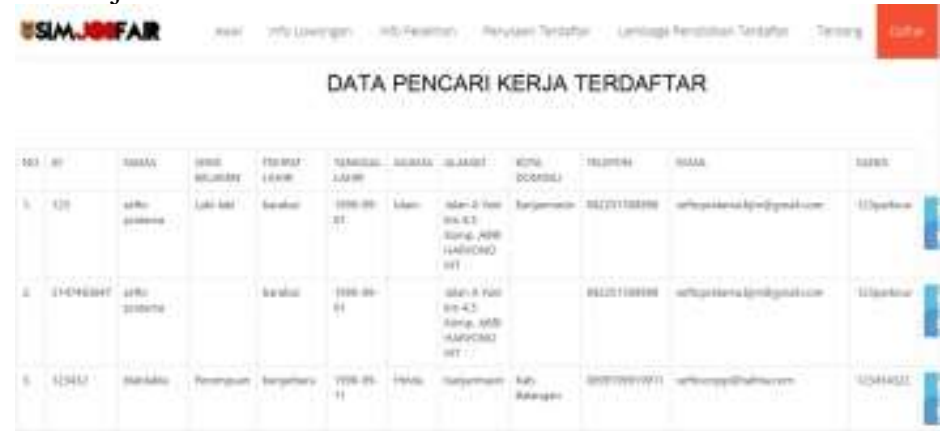

Gambar 9. Form Data Pencari Kerja Terdaftar

j. Form Data Lowongan Pekerjaan

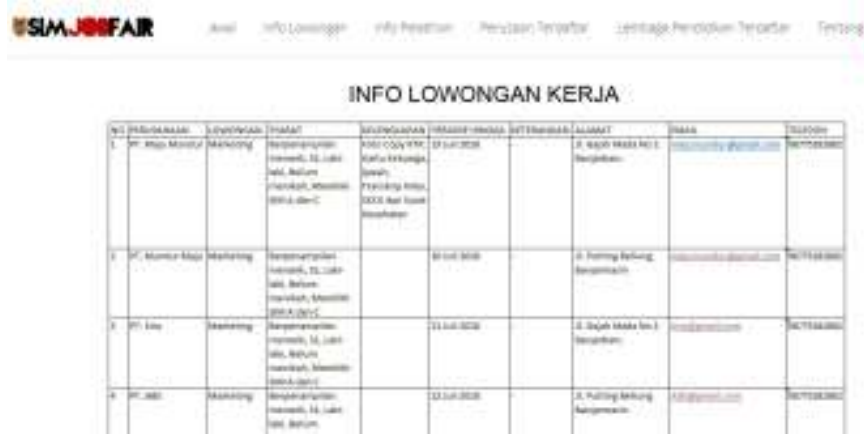

Gambar 10. Form Data Lowongan Pekerjaan 


\section{KESIMPULAN}

Kesimpulan dari penelitian yang telah dilakukan adalah sebagai berikut :

1. Dikarenakan banyak berkas yang hanya disimpan dilemari sehingga data penting tentang informasi perusahaan tidak di perbaharui.

2. Pergantian KA Bidang Penempatan dan Perluasan Kerja, dan seksi-seksinya mempunyai pengaruh dalam menggunakan sistem terdahulu.

3. Dengan adanya sistem yang baru, maka pencari kerja dapat dengan mudah mengakses dan mencari lowongan pekerjaan yang sesuai dengan keahlian maupun pendidikan.

4. Bagi penyedia kerja dapat dengan mudah mencari dan menemukan profil yang sesuai dengan dengan posisi yang dicari.

\section{REFERENSI}

[1] Kasiman, P. (2009). Aplikasi Web dengan PHP dan MySQL. Yogyakarta: ANDI.

[2] Peranginangin, K. (2006). Aplikasi WEB dengan PHP dan MySQL. Yogyakarta: ANDI.

[3] Hakim, Z. (2012, Agustus 16). Apa Itu Pemrograman Web? Retrieved April 2016, 28, from Pemrograman Web: http://www.zainalhakim.web.id/posting/ apa-itu-pemrograman-web.html

[4] Radhian, Fakkar Robbi. 2011. Flight Information Display System Pada Bandar Udara International Ahmad Yani Semarang. Semarang : Universitas Diponegoro

[5] Kadir, Abdul. 2008. Dasar Pemrograman Web Dinamis dengan Menggunakan PHP. Yogyakarta: ANDI

[6] Nugroho, Bunafit. 2004. Aplikasi Pemrograman Web Dinamis dengan PHP dan MySQL. Yogyakarta: GAVA MEDIA
[7] (Peraturan Menteri Tenaga Kerja dan Transmigrasi Republik Indonesia Nomor PER.15/MEN/X/2010 tentang Standar Pelayanan Minimal Bidang Ketengakerjaan)

[8] (Peraturan Menteri Tenaga Kerja dan Transmigrasi Republik Indonesia Nomor PER.15/MEN/X/2010 tentang Standar Pelayanan Minimal Bidang Ketengakerjaan) 